\title{
Effect of enzymatic complex in the diet of pirarucu, Arapaima gigas juveniles
}

\author{
Julliana de Castro LIMA ${ }^{1}$, Marianne SCHORER ${ }^{1 *} \oplus$, José Fernando Bibiano MELO², Luís Gustavo Tavares \\ BRAGA $^{1}$ \\ ' Universidade Estadual de Santa Cruz (UESC), Department of Agrarian and Environmental Sciences, Laboratory of Fish Nutrition (AQUANUT), 45662-900, Ilhéus, BA, Brazil \\ 2 Universidade Federal do Vale do São Francisco (UNIVASF), Department of Aquaculture, Campus Petrolina, Pernambuco, Brazil \\ * Corresponding author: marianne.schorer@gmail.com; (D) https://orcid.org/0000-0002-4931-3265
}

\begin{abstract}
The pirarucu, Arapaima gigas is a native, carnivorous fish species from the Amazon basin. As carnivorous fish have low amylase activity, exogenous enzymes can improve the digestibility of carbohydrates in aquaculture feeds. We evaluated the digestibility of increasing levels of an enzymatic complex in diets of pirarucu juveniles $(65.2 \pm 0.4 \mathrm{~g})$. The experimental design was randomized with four treatments [diets containing $0.25,0.50,0.75$, and $1 \mathrm{~g} \mathrm{~kg}^{-1}$ on-top inclusion of an enzyme complex (Allzyme ${ }^{\circ} \mathrm{SSF}^{\circ}$, USA), and a control, with three replications at a density of 5 fish per unit, and a 30-day duration. We quantified apparent digestibility of dry matter, crude protein, and crude energy through nutrient and chromium oxide content in diets and feces. Enzymatic activity, hepatic glycogen and total protein were determined in liver and anterior intestine samples. The diet with $1 \mathrm{~g} \mathrm{~kg}^{-1}$ of enzyme-complex resulted in an increase in apparent digestibility of crude protein, gross energy, and dry matter, hepatic glycogen, total proteins in liver and in intestine, showing the efficiency of the enzyme complex in pirarucu feeding. A higher accumulation of dry matter, crude energy, and ethereal extract in the carcass indicated weight increase in the fish treated with enzymatic complex. A decrease in the endogenous enzymatic activity (protease, lipase and amylase) suggested an improved efficacy of the digestive process. Our results indicate that the inclusion of $1 \mathrm{~g} \mathrm{~kg}^{-1}$ enzyme complex in the diet of juvenile pirarucu can be recommended to achieve greater digestibility of nutrients and improvement in productive performance.
\end{abstract}

KEYWORDS: additive, carnivorous fish, enzymes, enzymatic activity, metabolism, digestibility

\section{Efeito de complexo enzimático na dieta para juvenis de pirarucu, Arapaima gigas}

\section{RESUMO}

O pirarucu, Arapaima gigas é um peixe carnívoro nativo da bacia amazônica. Como peixes carnívoros possuem baixa atividade de amilase, enzimas exógenas melhoram a digestibilidade de carboidratos em raçôes para aquacultura. $\mathrm{O}$ objetivo deste estudo foi avaliar a digestibilidade de níveis crescentes de complexo enzimático em dietas para juvenis de pirarucu $(65,2 \pm 0,4 \mathrm{~g})$. O desenho experimental foi randomizado com quatro tratamentos [dietas contendo 0,25, 0,50, 0,75 e $1 \mathrm{~g} \mathrm{~kg}^{-1} \mathrm{de}$ complexo enzimático adicionado (Allzyme ${ }^{\oplus S F^{\ominus}}$, EUA)] e um controle, com três réplicas com densidade de cinco peixes por unidade e 30 dias de duração. A digestibilidade aparente da matéria seca, proteína bruta e energia bruta foi calculada por quantificação de nutrientes e óxido de cromo nas dietas e fezes. A atividade enzimática, o glicogênio hepático e a proteína total foram determinados a partir de amostras do fígado e intestino anterior. A dieta com $1 \mathrm{~g} \mathrm{~kg}^{-1}$ de complexo enzimático resultou em um aumento da digestibilidade aparente de proteina bruta, energia bruta, matéria seca, glicogênio hepático e proteínas totais no fígado e intestino, mostrando a eficácia do complexo enzimático na dieta dos pirarucus. A acumulação mais alta de matéria seca, energia bruta e extrato etéreo na carcaça indicou o aumento de peso dos peixes tratados com complexo enzimático. A redução da atividade enzimática endógena (protease, lipase e amilase) sugeriu um aumento da eficácia do processo digestivo. Nossos resultados indicam que a inclusão de $1 \mathrm{~g} \mathrm{~kg}^{-1}$ do complexo enzimático na dietas de juvenis de pirarucu pode ser recomendada para obter maior digestibilidade de nutientes e performance produtiva.

PALAVRAS-CHAVE: aditivo, atividade enzimática, enzimas, metabolismo, peixes carnívoros, digestibilidade 


\section{INTRODUCTION}

Arapaima gigas (Schinz 1822), popularly known in Brazil as pirarucu, is a carnivorous fish native to the Amazon basin (Ituassú et al. 2005). It has desirable characteristics for aquaculture, such as a good growth rate and productivity at high densities and in different production systems, and is of great economical importance in fish farming in the Amazon region (Cavero et al. 2004; Ituassú et al.2005; Nuñes et al. 2011; Oliveira et al. 2012). In 2017 the Brazilian production of farmed pirarucu was of almost two thousand tons, with thousand tons coming from the northern region of the country (IBGE 2017).

Feeding is responsible for the largest production costs in intensive fish farming, particularly the farming of carnivorous species, due to their high protein requirement (Melo et al. 2012). The inclusion of vegetable protein in fish feed has been evaluated for several species, including pirarucu (Ayhan et al. 2008; Booth et al. 2013; Souza et al. 2014; Cipriano et al. 2016; Dalsgaard et al. 2012, 2016). This ingredient allows the use of food industry by-products, reducing production costs. The use of additives in the diet of carnivorous fish can increase digestibility coefficients, mainly those of vegetable components, and improve the productive performance of farmed animals, as the nutritional quality of the diet depends on the animals' ability to digest and absorb nutrients.

Enzymatic additives do not have nutritional value, but aid in the digestion and absorption of nutrients, break down anti-nutritional factors, and increase the digestibility of feed, especially in young animals with developing gastrointestinal systems (Campestrini et al. 2005; Guimarães et al. 2009). In the diets of carnivorous fish, the enzyme supplementation improved feed conversion, weight gain, and growth of Cichla sp. (Soares et al. 2008), Clarias gariepinus (Yildirim and Turan 2010), and Salmo trutta caspius (Zamini et al. 2014). Addition of enzyme complex also increased the digestibility of diets containing plant proteins in rainbow trout, Oncorhynchus mykiss (Dalsgaard et al. 2012; 2016), juveniles of golden bream, Sparus aurata (Ayhan et al. 2008 ), and Atlantic salmon, Salmo salar (Jacobsen et al. 2018). The additive also increased phosphorus absorption in rainbow trout, decreasing the concentration of the mineral in feces (Sugiura et al. 2001); and increased the enzymatic activity, richness and diversity of the intestinal microbiota of Scophthalmus maximus (Diógenes et al. 2018).

Therefore the aim of this study was to evaluate the digestibility of increasing levels of enzymatic complex in diets of pirarucu juveniles, the main stage of development and growth in fish.

\section{MATERIAL AND METHODS}

The study was authorized by the Ethics Commission of Animal Use - CEUA of Universidade Estadual de Santa Cruz, Brazil (process no. 023/2017).

Pirarucu juveniles $(65.2 \pm 0.4 \mathrm{~g})$ were distributed in a completely randomized design into 15 digestibility aquariums $(210 \mathrm{~L})$, with four treatments of a test diet containing increasing levels of the enzyme complex: $0.25,0.5,0.75$, and $1.00 \mathrm{~g} \mathrm{~kg}^{-1}$, and a control diet without addition of the additive $\left(0.00 \mathrm{~g} \mathrm{~kg}^{-1}\right)$. Three replications were used for each treatment and the control, at a density of five fish per aquarium. ). Fish were fed three times a day (at 08:00, 12:00, and 16:00) until apparent satiety and were exposed to the experimental diets for 30 days. The aquariums were adapted for feces collection in a closed system, with recirculation of water through pumps and a biological filter, and with constant aeration and thermostatcontrolled heating $\left(28^{\circ} \mathrm{C}\right)$.

The test diets were isoproteic and isocaloric (Cipriano et al. 2015; 2016), formulated by the SUPER CRAC ${ }^{\oplus}$ program. Protein sources were fish meal, meat and bone meal, poultry by-products and soybean meal (Table 1). The reference feed was processed in the AQUANUT laboratory. The ingredients were homogenized ( $800 \mu \mathrm{m}$ mesh) and mixed in an automatic "V" mixer. Increasing levels of an enzyme complex (Allzyme $\mathrm{SSF}^{\oplus}$, Alltech Inc., Nicholasville, Kentucky, USA) were applied on top by spraying, after diet extrusion processing. The enzyme complex is derived from the fungus Aspergillus niger, and composed of pectinase 4,000 IU kg-1, protease $700 \mathrm{IU} \mathrm{kg}{ }^{-1}$, phytase $300 \mathrm{IU} \mathrm{kg}{ }^{-1}, \beta$-glucanase $200 \mathrm{IU} \mathrm{kg}{ }^{-1}$, xylanase $100 \mathrm{IU} \mathrm{kg}^{-1}$, cellulase $40 \mathrm{IU} \mathrm{kg}^{-1}$, and amylase $30 \mathrm{IU}$ $\mathrm{kg}^{-1}$, as determined by the manufacturer, and we added $0.1 \mathrm{~g}$ $\mathrm{kg}^{-1}$ of chromium oxide III $\left(\mathrm{Cr}_{2} \mathrm{O}_{3}\right)$, an external inert marker (Bremer Neto et al. 2003). All feeds were pelletized using the 4-6 mm matrix, and water $\left(35^{\circ} \mathrm{C}\right)$ was added to the process. Finally, the feeds were further dried with forced ventilation at $50{ }^{\circ} \mathrm{C}$ for 24 hours.

Water quality variables were monitored daily with a multiparameter probe (Hanna HI 9829, HANNA Instruments ${ }^{\circledR}$, Tamboré Barueri, Brazil) and a bench top photo colorimeter (Hanna 83203, HANNA Instruments ${ }^{\circ}$, Tamboré Barueri, Brazil). We recorded the following parameter values over the 30 days of the experiment $($ mean \pm SD): temperature $=27.87$ $\pm 0.36{ }^{\circ} \mathrm{C} ; \mathrm{pH}=6.55 \pm 0.23$; dissolved oxygen $=5.05 \pm 0.57$ $\mathrm{mg} \mathrm{L}^{-1}$; ammonia $=0.55 \pm 0.27 \mathrm{mg} \mathrm{L}^{-1}\left(\mathrm{NH}_{3}\right)$.

Feces collection started on the 4th day after fish started to receive the experimental diets, and was performed daily at 08:00 and 16:00, always after feeding. The collectors remained surrounded by Styrofoam and ice to maintain the characteristics of the sample. Collected feces were centrifuged (5000 rpm for 10 minutes) (Mod. 5424, Hamburg, Germany), frozen $\left(-80{ }^{\circ} \mathrm{C}\right)$, and lyophilized $\left(-40{ }^{\circ} \mathrm{C}\right)$ for subsequent determination of the chromium-oxide marker 
Table 1. Composition of the experimental diets used for pirarucu, Arapaima gigas juveniles in this study.

\begin{tabular}{|c|c|c|c|c|c|}
\hline \multirow{2}{*}{ Ingredients (\%) } & \multicolumn{5}{|c|}{ Enzymatic complex ( $\mathrm{g} \mathrm{kg}^{-1}$ feed) } \\
\hline & 0.00 & 0.25 & 0.50 & 0.75 & 1.00 \\
\hline Wheat bran $16 \%$ & 161.00 & 161.00 & 161.00 & 161.00 & 161.00 \\
\hline Soybean meal $45 \%$ & 274.00 & 274.00 & 274.00 & 274.00 & 274.00 \\
\hline Corn gluten bran $60 \%$ & 149.97 & 149.72 & 149.47 & 149.22 & 148.97 \\
\hline Fish meal 55\% & 60.00 & 60.00 & 60.00 & 60.00 & 60.00 \\
\hline Meat and bone meal 45\% & 110.00 & 110.00 & 110.00 & 110.00 & 110.00 \\
\hline Corn meal & 120.00 & 120.00 & 120.00 & 120.00 & 120.00 \\
\hline Poultry by-products $58 \%$ & 71.00 & 71.00 & 71.00 & 71.00 & 71.00 \\
\hline Soy oil & 45.00 & 45.00 & 45.00 & 45.00 & 45.00 \\
\hline Premix Vitamin Minerals ${ }^{1}$ & 5.00 & 5.00 & 5.00 & 5.00 & 5.00 \\
\hline Common salt & 2.87 & 2.87 & 2.87 & 2.87 & 2.87 \\
\hline Antifungal $\mathrm{BHT}^{2}$ & 0.80 & 0.80 & 0.80 & 0.80 & 0.80 \\
\hline Antioxidant & 0.13 & 0.13 & 0.13 & 0.13 & 0.13 \\
\hline Vitamin C & 0.20 & 0.20 & 0.20 & 0.20 & 0.20 \\
\hline Enzymatic complex ( $\mathrm{g} \mathrm{kg}^{-1}$ feed) & 0.00 & 0.25 & 0.50 & 0.75 & 1.0 \\
\hline Chromium oxide ( $\mathrm{g} \mathrm{kg}^{-1}$ feed) & 0.1 & 0.1 & 0.1 & 0.1 & 0.1 \\
\hline \multicolumn{6}{|l|}{ Chemical composition } \\
\hline Dry matter (\%) & 93.4570 & 93.0851 & 93.4570 & 93.2771 & 92.6111 \\
\hline Crude protein (\%) & 42.0621 & 42.0597 & 42.1240 & 42.0853 & 42.0770 \\
\hline Gross energy $\left(\mathrm{kcal} \mathrm{kg}^{-1}\right)$ & 4947 & 5173 & 4857 & 4992 & 4960 \\
\hline Mineral matter (\%) & 11.1587 & 10.9034 & 10.9638 & 10.9468 & 10.6763 \\
\hline Crude fiber (\%) & 3.6646 & 3.6646 & 3.6646 & 3.6646 & 3.6646 \\
\hline Total phosphorus (\%) & 1.5557 & 1.5557 & 1.5557 & 1.5557 & 1.5557 \\
\hline Lysine (\%) & 1.9728 & 1.9728 & 1.9728 & 1.9728 & 1.9728 \\
\hline Methionine + Total cystine (\%) & 1.3952 & 1.3952 & 1.3952 & 1.3952 & 1.3952 \\
\hline Methionine (\%) & 0.7926 & 0.7926 & 0.7926 & 0.7926 & 0.7926 \\
\hline Starch (\%) & 15.1370 & 15.1370 & 15.1370 & 15.1370 & 15.1370 \\
\hline Calcium (\%) & 2.1105 & 2.1105 & 2.1105 & 2.1105 & 2.1105 \\
\hline
\end{tabular}

'Mineral vitamin supplement (composition per $\mathrm{kg}$ of product): vitamin $\mathrm{A}=6,000,000 \mathrm{IU}$; vitamin $\mathrm{D} 3=2,250,000 \mathrm{IU}$; vitamin $\mathrm{E}=75,000 \mathrm{mg}$; vitamin $\mathrm{K} 3=3,000 \mathrm{mg}$; vitamin thiamine = 5,000 mg; riboflavin = 10,000 mg; pyrodoxine vitamin = 8,000 mg; biotin = 2,000 mg; vitamin C = 192,500 mg; niacin = 30,000 mg; folic acid =

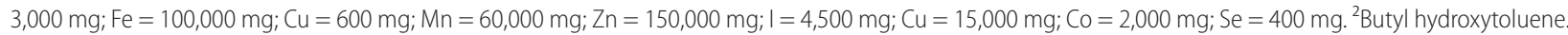

concentration by nitric acid and hydrogen peroxide digestion, and quantification using an Inductively Coupled Plasma Optical Emission Spectrophotometer (ICP-OES, Malvern Panalytical, Malvern, UK) (Willians et al. 1962). Feces were collected for 21 days (from the 4th to the 24th day of the experimental period). We based the calculation of the apparent digestibility coefficients on the concentration of chromium oxide and nutrients (Table1) present in the feeds and feces, according to the formula:

$$
A D=100-\left[100\left(\frac{\% \mathrm{Cr}_{2} \mathrm{O}_{3 \text { feed }}}{\% \mathrm{Cr}_{2} \mathrm{O}_{3 \text { feces }}}\right) \times\left(\frac{\% N_{\text {feces }}}{\% N_{\text {feed }}}\right)\right]
$$

where: $\mathrm{AD}=$ apparent digestibility; $\% \mathrm{Cr}_{2} \mathrm{O}_{3}=$ percentage of chromium oxide; and $\% \mathrm{~N}=$ percentage of nutrient (Bremer Neto et al. 2003).

At the end of the 30-day experimental period all fish were euthanized ( $25 \mathrm{mg} \mathrm{L}^{-1}$ benzocaine) and had their liver and intestine dissected. The activity of the digestive enzymes, amylase and lipase, and total proteins in the anterior portion of the intestine and the enzyme aspartate aminotransferase and total proteins in the liver were determined by Labtest kits. Alkaline protease activity was determined according to Walter (1984) and liver glycogen concentration according to Bidinotto et al. (1997). The fish (whole body and eviscerated) were then lyophilized and ground for the chemical analysis of the carcass.

Samples of dry matter of the feces and carcass were frozen $\left(-80^{\circ} \mathrm{C}\right)$ and lyophilized by a sublimation process at $-40{ }^{\circ} \mathrm{C}$. The feeds were kiln-dried at $105^{\circ} \mathrm{C}$ for 24 hours. Mineral matter was determined by incinerating the samples in a muffle furnace at $600{ }^{\circ} \mathrm{C}$ for 4 hours. The crude protein content was calculated from the quantification of total nitrogen in the samples by the Kjeldahl method, multiplied by the conversion factor 6.25. The ethereal extract was determined by continuously washing the samples in petroleum ether at $90{ }^{\circ} \mathrm{C}$, according to the Goldfish method. These analyzes were performed following Detmann et al. (2012), and gross energy was determined with a calorimetric pump (IKA C-200, Labcontrol, São Paulo, Brazil).

Data were submitted to analysis of residual normality (Shapiro-Wilk test) and homoscedasticity of variances (Bartlett's test). The relation of apparent digestibility coefficient, enzymatic activity, and total protein and hepatic glycogen concentrations with the level of enzyme complex was analyzed with simple regression analysis. Carcass chemical composition data was compared among diets with analysis of variance (ANOVA) and a post-hoc Tukey test (at 5\% 
probability level). All analyses were carried out with the $\mathrm{R}$ program, version 3.4 .0 (2017).

\section{RESULTS}

There was better apparent digestibility in pirarucus fed with diets, including the enzymatic complex. The experimental diets have a quadratic effect (Table 2), with optimal levels of enzyme complex at $0.88 \mathrm{~g} \mathrm{~kg}^{-1}, 0.81 \mathrm{~g} \mathrm{~kg}^{-1}$, and $0.79 \mathrm{~g} \mathrm{~kg}^{-1}$, for crude protein, gross energy and dry matter, respectively.

The digestive enzymes evaluated (alkaline protease, amylase, and lipase) in the intestinal tract decreased linearly with increasing levels of enzyme complex (Table 3). The glycogen concentration in the liver increased linearly with increasing levels of enzyme complex, with values ranging from 45.38 to $75.49 \mu \mathrm{mol} \mathrm{g}^{-1}$.

Percentages of dry matter, crude energy, and ether extract in the carcasses varied significantly among the experimental diets (Table 4), but the percentage of crude protein in the carcass did not vary significantly.

\section{DISCUSSION}

The major functions of exogenous enzymes in fish feeds are to promote the removal of anti-nutritional factors, mainly from plant foods, improve the digestibility of the diet, stimulate endogenous enzymatic action and reduce environmental pollution that is caused by the excretion of

Table 2. Apparent digestibility of crude protein, crude energy and dry matter (mean \pm standard error) of experimental diets with increasing levels of enzymatic complex in feed for juvenile pirarucu, Arapaima gigas.

\begin{tabular}{|c|c|c|c|c|c|c|c|c|}
\hline \multirow{2}{*}{ Apparent digestibility } & \multicolumn{5}{|c|}{ Enzymatic complex ( $\mathrm{g} \mathrm{kg}^{-1}$ feed) } & \multicolumn{3}{|c|}{ Regression model } \\
\hline & $0.00^{*}$ & 0.25 & 0.50 & 0.75 & 1.00 & model & $r^{2}$ & $p$-value \\
\hline Crude protein (\%) & $81.29 \pm 0.19$ & $79.62 \pm 1.21$ & $78.07 \pm 0.11$ & $86.25 \pm 0.07$ & $89.08 \pm 0.09$ & $21.42 x^{2}-12.54 x+81.10$ & 0.86 & $4.41 \times 10^{-9}$ \\
\hline Gross energy (\%) & $67.54 \pm 2.05$ & $74.34 \pm 0.39$ & $62.18 \pm 0.51$ & $76.58 \pm 0.09$ & $82.81 \pm 0.16$ & $29.07 x^{2}-15.96 x+69.77$ & 0.60 & $4.04 \times 10^{-8}$ \\
\hline Dry matter (\%) & $64.84 \pm 0.00$ & $72.57 \pm 0.00$ & $58.67 \pm 0.01$ & $75.02 \pm 0.01$ & $82.09 \pm 0.00$ & $33.04 x^{2}-18.25 x+67.38$ & 0.59 & $<2.00 \times 10^{-15}$ \\
\hline
\end{tabular}

${ }^{*}$ control

Table 3. Digestive enzyme activity, total protein and hepatic glycogen concentrations (mean \pm standard error) of juvenile pirarucu, Arapaima gigas fed with increasing levels of enzyme complex.

\begin{tabular}{|c|c|c|c|c|c|c|c|c|}
\hline & \multicolumn{5}{|c|}{ Enzymatic complex ( $\mathrm{g} \mathrm{kg}^{-1}$ feed) } & \multicolumn{3}{|c|}{ Regression model } \\
\hline & $0.00^{*}$ & 0.25 & 0.50 & 0.75 & 1.00 & model & $r^{2}$ & $p$ value \\
\hline Alkaline protease $\left(U \mu^{-1}\right)$ & $11.29 \pm 2.60$ & $5.66 \pm 0.00$ & $4.57 \pm 1.99$ & $1.42 \pm 0.03$ & $1.64 \pm 0.14$ & $-9.42 x+9.62$ & 0.86 & $5.28 \times 10^{-4}$ \\
\hline Lipase $\left(U \mathrm{mg}^{-1}\right)$ & $8.22 \pm 0.79$ & $3.77 \pm 0.12$ & $3.74 \pm 1.72$ & $5.23 \pm 0.41$ & $0.22 \pm 0.04$ & $-5.82 x+7.15$ & 0.63 & $1.47 \times 10^{-5}$ \\
\hline Amylase $\left(\mathrm{U} \mathrm{mg}^{-1}\right)$ & $16.76 \pm 1.36$ & $7.61 \pm 0.99$ & $12.83 \pm 1.11$ & $10.53 \pm 0.14$ & $3.30 \pm 0.08$ & $-9.60 x+15.01$ & 0.55 & $1.76 \times 10^{-6}$ \\
\hline Hepatic glycogen ( $\left.\mu \mathrm{mol} \mathrm{g}^{-1}\right)$ & $45.38 \pm 1.47$ & $49.09 \pm 2.05$ & $52.62 \pm 1.82$ & $73.92 \pm 4.45$ & $75.49 \pm 3.89$ & $34.02 x+42.29$ & 0.88 & $4.11 \times 10^{-5}$ \\
\hline Aspartate aminotransferase $\left(\mathrm{U} \mathrm{mg}^{-1}\right)$ & $1.83 \pm 0.11$ & $2.79 \pm 0.36$ & $2.22 \pm 0.08$ & $2.29 \pm 0.06$ & $2.84 \pm 0.17$ & - & - & 0.26 \\
\hline Total proteins in the liver ( $\mathrm{g} \mathrm{dL}^{-1}$ ) & $5.80 \pm 1.07$ & $3.94 \pm 0.37$ & $5.61 \pm 1.39$ & $3.83 \pm 0.24$ & $4.84 \pm 0.47$ & - & - & 0.37 \\
\hline Total protein in the intestine $\left(\mathrm{g} \mathrm{dL}^{-1}\right)$ & $1.37 \pm 0.02$ & $2.64 \pm 0.76$ & $2.38 \pm 0.48$ & $3.51 \pm 0.35$ & $5.52 \pm 0.71$ & $3.68 x+1.25$ & 0.86 & $2.86 \times 10^{-4}$ \\
\hline
\end{tabular}

${ }^{*}$ control

Table 4. Chemical composition (mean \pm standard error) of the carcass of pirarucu, Arapaima gigas juveniles submitted to diets with increasing levels of enzymatic complex.

\begin{tabular}{|c|c|c|c|c|c|c|}
\hline & \multicolumn{5}{|c|}{ Enzymatic complex ( $\mathrm{g} \mathrm{kg}^{-1}$ feed) } & \multirow{2}{*}{$p$ value } \\
\hline & $0.00^{*}$ & 0.25 & 0.50 & 0.75 & 1.00 & \\
\hline Crude protein (\%) & $63.12 \pm 0.38 a$ & $64.36 \pm 0.31 a$ & $63.50 \pm 0.42 \mathrm{a}$ & $60.63 \pm 0.45 a$ & $58.90 \pm 0.61 a$ & 0.06 \\
\hline Gross energy ( $\mathrm{kcal} \mathrm{kg}^{-1}$ ) & $4320 \pm 31.75 b$ & $4378 \pm 17.90 b$ & $4700 \pm 61.49 a$ & $4310 \pm 4.33 b$ & $4718 \pm 62.00 a$ & $4.47 \times 10^{-4}$ \\
\hline Dry matter (\%) & $23.41 \pm 0.00 d$ & $22.92 \pm 0.01 e$ & $24.05 \pm 0.01 c$ & $24.10 \pm 0.00 \mathrm{~b}$ & $25.64 \pm 0.00 \mathrm{a}$ & $2.00 \times 10^{-15}$ \\
\hline Mineral matter (\%) & $23.13 \pm 0.16 b$ & $21.36 \pm 0.01 \mathrm{C}$ & $24.18 \pm 0.07 a$ & $24.00 \pm 0.17 a$ & $21.87 \pm 0.07 c$ & $2.42 \times 10^{-6}$ \\
\hline Ethereal extract (\%) & $6.47 \pm 0.11 c$ & $6.32 \pm 0.16 c$ & $10.55 \pm 0.13 b$ & $9.53 \pm 0.36 b$ & $12.49 \pm 0.30 a$ & $1.50 \times 10^{-7}$ \\
\hline
\end{tabular}

The $p$-values refer to an ANOVA of the comparison among treatments. Same letters in the same line indicate that the values did not differ significantly between treatments according to a Tukey test.Values are expressed based on dry matter. ${ }^{*}$ control. 
nutrients. In our study, the enzymatic complex improved the digestibility of crude protein, crude energy and dry matter of the diet. Several other studies demonstrate the positive effects of the exogenous enzyme complex in fish feed on fish performance, microbiota, growth or digestive diseases (Ai $e t$ al. 2007; Silva et al. 2007; Guimarães et al. 2009; Signor et al. 2010; Yildirim et al. 2010; Bedford and Cowieson 2012; Dalsgaard et al. 2012; 2016; Zamini et al, 2014; Adeoyde et al. 2016; Ramos et al. 2017; Jacobsen et al. 2018). Therefore, exogenous enzymes are widely used, as they increase the feed utilization and digestibility, enhance growth performance and optimize whole-body composition, promotes immune performance and pathogen resistance, and impacts the fish microbiota (Zheng et al. 2019).

Improvements in protein digestibility in fish are associated with the absorption of nutrients, and with the action of endogenous and exogenous proteases (Guimarães et al. 2009; Yin et al. 2001). Increased protease activity is essential to increase protein digestibility and fast absorption (HlopheGinindza et al. 2015). In the present study, the levels of alkaline protease, lipase and amylase in the intestinal tract of the pirarucus decreased linearly with the increase in the level of the enzyme complex. This is explained by the capacity of the exogenous enzyme supplementation to promote the secretion of endogenous enzymes by the fish, improving digestibility (Lin and Tan 2007). For example, a part of the protein intake by the fish may have been used for the synthesis of enzymes, and the exogenous enzymes ended up reducing the synthesis of endogenous enzymes for the use of proteins for muscle growth (Yin et al. 2001). The end effect, however, was that the crude protein level of the carcasses did not differ among treatments. Energy increases with the digestibility of nutrients in the diet, as well as with proteins, carbohydrates and lipids, which are used by fish as sources of energy (Meyer et al. 2004). In the present study, the digestibility of the diet's dry matter increased with the enzyme-complex increments, which can be mainly attributed to the increased digestibility of the diet's ingredients.

The increase in the level of hepatic glycogen with the enzyme complex in the diet was probably related to the amylase in the enzymatic complex, as this enzyme breaks the glycosidic bonds of polysaccharides such as starch, making glucose available from the ingredients of the diet formulation and causing glycogen deposition in the liver (Hemre et al. 2002). In Rhamdia quelen, low glycogen levels and high total protein levels in the liver $(49.9 \pm 4.2$ and $64.3 \pm 2.5 \mathrm{U}$ $\mathrm{mg}^{-1}$, respectively) were associated with increased aspartate aminotransferase activity (687.9 to $\left.1028.6 \mathrm{U} \mathrm{mg}^{-1}\right)$ as a sign of protein catabolism and energy deficiency (Pretto et al. 2014).

Cellulase, xylanase, betaglucanase, and pectinase in the diet degrade plant-cell walls, and non-starch polysaccharides, considered anti-nutritional factors (Brito et al. 2008), to provide dietary carbohydrates (Silva et al. 2007). Soy, for example, has non-starch polysaccharides in the form of pectins, hemicelluloses, and oligosaccharides (Brito et al. 2008), and protease and lectin inhibitors (Campestrini et al. 2005). Thus the carbohydrases in the dietary enzymatic supplementation used in our study allowed the pirarucu juveniles to use non-starch polysaccharides as energy sources, reducing the amount of non-digestible residues (Brito et al. 2008).

In our study, the level of enzyme complex did not influence the activity of the enzyme aspartate aminotransferase in pirarucu. The activity of aspartate aminotransferase, one of the major enzymes involved in protein metabolism, is associated with amino acid transamination for energy production and excretion of nitrogenous compounds (Melo et al. 2006; Souza et al. 2014). The activity of aspartate aminotransferase associated with the absence of changes in the total protein concentration in the liver suggests that the pirarucu used the ingested protein for muscle synthesis. Our results thus support the use of enzymatic activity enhancers as a tool to modulate the use of nutrients in the diet of pirarucu, allowing adjustments to avoid protein catabolism as an energy source (Melo et al. 2016).

Ituassú et al. (2005) evaluated the effect of different protein levels in the diet of pirarucu juveniles on the chemical composition of the carcasses and reported similar values to our study for dry matter (15.1 to $20.5 \%$ ), mineral matter (17 to $19.2 \%$ ), crude protein (64.3 to $68.8 \%$ ), and ethereal extract (6.5 to $12.6 \%$ ). These similar values are probably related to that the animals in both studies were in the same weight range $(99.08 \pm 17.38 \mathrm{~g}$ in Ituassú et al. 2005), as age is one of the factors that influences muscle composition. In our study, levels of dry matter, crude energy and ether extract in the carcass increased with the levels of enzyme complex. In Hungarian carp (Cyprinus carpio), the inclusion of phytase increased the ash content but decreased the ethereal extract content in carcasses (Rocha et al. 2010), while in tilapia Oreochromis niloticus, the addition of an enzyme complex in diets had no effect on carcass chemical composition (Signor et al. 2010).

Ethereal extract in the carcass of the pirarucus increased with the digestibility of crude energy and the level of inclusion of the enzyme complex in the diet. Increased energy digestibility improves glycogen levels in the liver, which, in excess, stimulates lipogenesis, increasing the amount of fat deposited in the carcass (Hemre et al. 2002), as observed in our study, indicating that the use of the enzyme complex stimulated lipogenesis in the juvenile pirarucu. In addition, our pirarucus were kept in small digestibility aquariums that restrict swimming, and the increase in fat deposition in the carcasses is known to be intensified under cultivation conditions (Arbeláez-Rojas et al. 2002; Machado and Foresti 2009). 


\section{CONCLUSIONS}

The inclusion of an enzyme complex in diet of pirarucu juveniles increased the apparent digestibility of nutrients, hepatic glycogen, and total proteins in liver and intestine, and promoted an increase in dry matter, crude energy, and ethereal extract in the carcass, and a decrease in the endogenous activity of the protease, lipase and amylase. These results indicate that the addition of enzyme complex to the diet of aquacultured juvenile pirarucu improves their weight and the efficacy of the digestive process.

\section{ACKNOWLEDGMENTS}

We are thankful to Fundação de Amparo à Pesquisa da Bahia (FAPESB) - PRONEM (013/2014), process k; Coordenação de Aperfeiçoamento de Pessoal de Nível Superior (CAPES); Pratigi Alimentos for preparing the base feed; MARWAY FARM for supplying the fish; the team of the laboratories of Fish Nutrition and Feeding (AQUANUT"), Animal Nutrition (LABNUT - Universidade Estadual de Santa Cruz), Aquaculture (Universidade Federal do Vale do São Francisco), and Analytical Chemistry Research (LPQA UESC); and to the professors Dr. Raildo Mota de Jesus, and Dr. Wilson Massamitu Furuya.

\section{REFERENCES}

Adeoyde A.A.; Jaramillo-Torres, A.; Fox, S.W.; Merrifield, D.L.; Davies, S.J. 2016. Supplementation of formulated diets for tilapia (Oreochromis niloticus) with selected exogenous enzyme: Overall performance and effects on intestinal histology and microbiota. Animal Feed Science and Technology., 215: 133-143.

Ai, Q.; Mai, K.; Zhang, W.; Xu, W.; Tan, B.; Zhang, C.; Li, H. 2007. Effects of exogenous enzymes (phytase, nonstarch polysaccharides enzyme) in diets on growth, feed utilization, nitrogen and phosphorus excretion of Japanese seabass, Lateolabrax japonicus. Comparative Biochemistry and Physiology Part A: Molecular \& Integrative Physiology, 147: 502-508

Arbeláez-Rojas, G.A.; Fracalossi, D.M.; Fim, J.D.I. 2002. Composição corporal de tambaqui; Colossoma macropomum; e matrinxã; Brycon cephalus; em sistemas de cultivo intensivo; em Igarapé; e semi-intensivo; em viveiros. Revista Brasileira de Zootecnia, 31: 1059-1069.

Ayhan, V.; Diler, I.; Arabaci, M.; Sevgili, H. 2008. Enzyme supplementation to soybean based diet in Gilthead Sea Bream (Sparus aurata): Effects on growth parameters and nitrogen and phosphorus excretion. Kafkas Üniversitesi Veteriner Fakültesi Dergisi, 14: 161-168.

Bedford, M.R.; Cowieson, A.J. 2012. Exogenous enzyme and their effects on intestinal microbiology. Animal Feed Science and Technology, 173: 76-85

Booth, M.A.; Moses, M.D.; Allan, G.L. 2013. Utilization of carbohydrate by yellowtail kingfish. Seriola lalandi. Aquaculture, 376: 151-161.
Bremer Neto, H.; Graner, C.A.F.; Pezzato, L.E.; Padovani, C.R.; Cantelmo, O.A. 2003. Reduction in chromium (III) oxide level as an external marker. Revista Brasileira de Zootecnia, 32: 249-255.

Brito, M.S.; de Oliveira, C.F.S.; da Silva, T.R.G.; de Lima, R.B.; Morais, S.N.; da Silva, J.H.V. 2008. Polysaccharides not amylaceous in the monogastric nutrition - Revision. Acta Veterinária Brasilica, 2: 111-117.

Cavero, B.A.S.; Pereira-Filho, M.; Bordinhon, A.M.; Fonseca, F.A.L.; Ituassú, D.R.; Roubach, R; Ono, E.A. 2004. Tolerância de juvenis de pirarucu ao aumento da concentração de amônia em ambiente confinado. Pesquisa Agropecuária Brasileira, 39: 513- 516.

Campestrini, E.; Silva, V.T.M.; Appelt, M.D. 2005. Utilização de enzimas na alimentação animal. Nutritime, 2: 254-267.

Cipriano, F.D.S.; Lima, K.S.D.; Souza, R.H.B.D.; Tonini, W.C.T.; Passinato, E.B.; Braga, L.G.T. 2016. Digestibility of animal and vegetable protein ingredients by pirarucu juveniles; Arapaima gigas. Revista Brasileira de Zootecnia, 45: 581-586.

Cipriano, F.S.; Santos de Lima, K.; Bevitório-Passinato, É.; Mota de Jesus, R.; Magalhães Júnior, F.O.; Teles-Tonini, W.C.; TavaresBraga, L.G. 2015. Apparent digestibility of energetic ingredients by pirarucu juveniles; Arapaima gigas (Schinz; 1822). Latin American Journal of Aquatic Research, 43: 786-791.

Dalsgaard, J.; Velhac, V.; Hjermitslev, N.H.; Ekmann, K.S.; Fischer, M.; Klausen, M.; Pedersen, P.B. 2012. Effects of exogenous enzyme on apparent nutrient digestibility in rainbow trout (Oncorhynchus mykiss) fed diets with high inclusion of plantbased protein. Animal Feed Science and Technology, 171: 181-191.

Dalsgaard, J.; Bach Knudsen, K.E.; Verlhac, V.; Ekmann, K.S.; Pedersen, P.B. 2016. Supplementing enzymes to extruded; soybean-based diet improves breakdown of nonstarch polysaccharides in rainbow trout (Oncorhynchus mykiss). Aquaculture Nutrition, 22: 419-426.

Dalsgaard, J.; Verlhac, V.; Hjermitslev, N. H.; Ekmann, K. S.; Fischer, M.; Klausen, M.; Pedersen, P.B. 2012. Effects of exogenous enzymes on apparent nutrient digestibility in rainbow trout (Oncorhynchus mykiss) fed diets with high inclusion of plantbased protein. Animal Feed Science and Technology, 171: 181-191.

Detmann, E; de Souza, M.A.; Valadares Filho, S.C.; de Queiroz, A.C.; Berchielli, T.T.; Saliba, E.O.S.; Cabral, L.S.; Pina, D.S.; Ladeira, M.M.; Azevedo, J.A.G. 2012. Métodos de para Análise de Alimentos. 3rd ed. Universidade Federal de Viçosa, Minas Gerais, 166p.

Guimarães, I.G.; Falcon, D.R.; Schich, D.; Barros, M.M.; Pezzato, L.E. 2009. Apparent digestibility of diets containing enzyme supplement for Nile tilapia. Arquivo Brasileiro de Medicina Veterinária e Zootecnia, 61: 1397-1402.

Hemre, G.I.; Mommsen, T.P.; Krogdahl, Å. 2002. Carbohydrates in fish nutrition: effects on growth; glucose metabolism and hepatic enzymes. Aquaculture Nutrition, 8: 175-194.

Ituassú, D.R.; Pereira Filho, M.; Roubach, R.; Crescêncio, R.; Cavero, B.A.S.; Gandra, A.L. 2005. Crude protein levels for juvenile pirarucu. Pesquisa Agropecuária Brasileira, 40: 255-259.

IBGE. 2018. Censo Agropeuário de 2018. v.7. Instituto Brasileiro de Geografia e Estatística, Rio de Janeiro, 108p. 
Jacobsen, H.J.; Samuelsen, T.A.; Girons, A.; Kousoulaki, K. 2018. Different enzyme incorporation strategies in Atlantic salmon diet containing soybean meal: Effects on feed quality; fish performance; nutrient digestibility and distal intestinal morphology. Aquaculture, 491: 302-309.

Machado, M.R.F.; Foresti, F. 2009. Processing yield and chemical composition of the Prochilodus lineatus from Mogi Guaçu river; Brazil. Archivos de Zootecnia, 58: 663-670.

Melo, J.F.B.; Lundstedt, L.M.; Metón, I.; Baanante, I.V.; Moraes, G. 2006. Effects of dietary levels of protein on nitrogenous metabolism of Rhamdia quelen (Teleostei: Pimelodidae). Comparative Biochemenstry and Physiology: Molecular \& Integrative Physiology, 145: 181-187.

Melo, J.F.B.; Lundstedt, L.M.; Moraes, G.; Inoue, L.A.K.A. 2012. Effect of different concentrations of protein on the digestive system of juvenile silver catfish. Arquivo Brasileiro de Medicina Veterinária e Zootecnia, 64: 450-457.

Melo, J.F.B.; Lundstedt, L.M.; Inoue, L.A.K.; Metón, I.; Baanante, I.V.; Moraes, G. 2016. Glycolysis and gluconeogenesis in the liver of catfish fed with different concentrations of proteins; lipids and carbohydrates. Arquivo Brasileiro de Medicina Veterinária e Zootecnia, 68: 1251-1258.

Meyer, G.; Fracalossi, D.M.; Borba, M.R. 2004. A importância da quantidade de energia na raçáo de peixes. Panorama da Aquicultura, 14: 53-57.

Núñez, J.; Chu-Koo, F.; Berland, M.; Arévalo, L.; Ribeyro, O.; Duponchelle, F.; Renno, J.F. 2011. Reproductive success and fry production of the paiche or pirarucu, Arapaima gigas (Schinz), in the region of Iquitos, Perú. Aquaculture Research, 42: 815-822.

Oliveira, E.G.; Pinheiro, A.B.; de Oliveira, V.Q.; da Silva Júnior, A.R.M.; de Moraes, M.G.; Rocha, Í.R.C.B.; Costa, F.H.F. 2012. Effects of stocking density on the performance of juvenile pirarucu (Arapaima gigas) in cages. Aquaculture, 370: 96-101.

Ono, E.A.; Nunes, E.D.S.S.; Cedano, J.C.C.; Pereira Filho, M.; Roubach, R. 2008. Apparent digestibility coefficient of practical diets with different energy: protein ratios for pirarucu juveniles. Pesquisa Agropecuária Brasileira, 43: 249-254.

Pretto, A.; da Silva, L.P; Radünz Neto, J.; Nunes, L.M.C.; Freitas, I.L.; Loureiro, B.B.; dos Santos, S.A. 2014. Farelo de crambe nas formas in natura ou reduzida em antinutrientes na dieta do jundiá. Ciência Rural, 44: 692-698.

R Core Team. 2017. R: A Language and Environment for Statistical Computing. R Foundation for Statistical Computing, Vienna.

Ramos, L.R.V.; Pedrosa, V.F.; Mori, A.; Andrade, C.F.F.; Romano, L.A.; Abreu, P.C.; Tesser, M.B. 2017. Exogenous enzyme complex prevents intestinal soybean mealinduced enteritis in Mugil liza (Valenciennes, 1836) juvenile. Anais da Academia Brasileira de Ciências, 89: 341-353.
Rocha, C.B.; Pouey, J.L.F.; Piedras, S.R.N.; Enke, D.B.S.; Fernandes, J.M. 2010. Fitase na dieta de alevinos de carpa húngara: desempenho e características de carcaça. Arquivos Brasileiros de Medicina Veterinária e Zootecnia, 62: 1462-1468.

Signor, A.A.; Boscolo, W.R.B.; Feiden, F.; Sampaio, A.G.G.; Freitas, J.M.A. 2010. Desempenho de juvenis de tilápia-do-nilo alimentados com raçóes contendo complexo enzimático. Revista Braileira de Zootecnia, 39: 977- 983.

Silva, J.A.M.D.; Pereira Filho, M.; Cavero, B.A.S.; Pereira, M.I.D.O. 2007. Apparent digestibility of nutrients and crude energy in diets with addition of exogenous digestive enzymes in tambaqui juveniles (Colossoma macropomum Cuvier, 1818). Acta Amazonica, 37: 157-164.

Soares, E.C.; Pereira Filho, M.; Roubach, R.; Soares, R.C. 2008. Exogenous protease in diets for tucunaré paca (Cichla sp.) juvenile. Revista Brasileira de Zootecnia, 37: 971-976.

Souza, S.A.; Souza, R.C.; Campeche, D.F.B.; RML, C.; Melo, J.F.B. 2014. Evaluation of protein: carbohydrate ratio in the diet of hybrids of Pseudoplatystoma fasciatum (female) X Leiarius marmoratus (male). Arquivo Brasileiro de Medicina Veterinária e Zootecnia, 66: 879-886.

Sugiura, S.H.; Gabaudan, J.; Dong, F.M.; Hardy, R.W. 2001. Dietary microbial phytase supplementation and the utilization of phosphorus; trace minerals and protein by rainbow trout (Oncorhynchus mykiss (Walbaum)) fed soybean meal-based diets. Aquaculture Research, 32: 583-592.

Walter, H.E. 1984. Proteinases: Methods with Hemoglobin; Casein and Azocoll as Substrates. 1st ed. Verlag Chemie, Weinheim. 800p.

Yildirim, Y.B.; Turan, F. 2010. Effects of exogenous enzyme supplementation in diets on growth and feed utilization in African catfish; Clarias gariepinus. Journal of Animal and Veterináry Advances, 9: 327-331.

Yin, Y.L.; Baidoo, S.K.; Jin, L.Z.; Liu, Y.G.; Schulze, H.; Simmins, P.H. 2001. The effect of different carbohydrase and protease supplementation on apparent (ileal and overall) digestibility of nutrients of five hulless barley varieties in young pigs. Livestock Production Science, 71: 109-120.

Zamini, A.; Kanani, H.G.; Esmaeili, A.; Ramezani, S.; Zoriezahra, S.J. 2014. Effects of two dietary exogenous multi-enzyme supplementation; Natuzyme ${ }^{\odot}$ and beta-mannanase (Hemicell ${ }^{\odot}$ ), on growth and blood parameters of Caspian salmon (Salmo trutta caspius). Comparative Clinical Pathology, 23: 187-192.

Zheng, C-C.; Wu, J.W.; Jin, Z.; Ye, Z. 2019. Exogenous enzymes as functional additives in finfish aquaculture. Aquaculture Nutrition, 26: $213-224$.

RECEIVED: $22 / 07 / 2020$

ACCEPTED: 30/03/2021

ASSOCIATE EDITOR: Rodrigo R. do Valle 